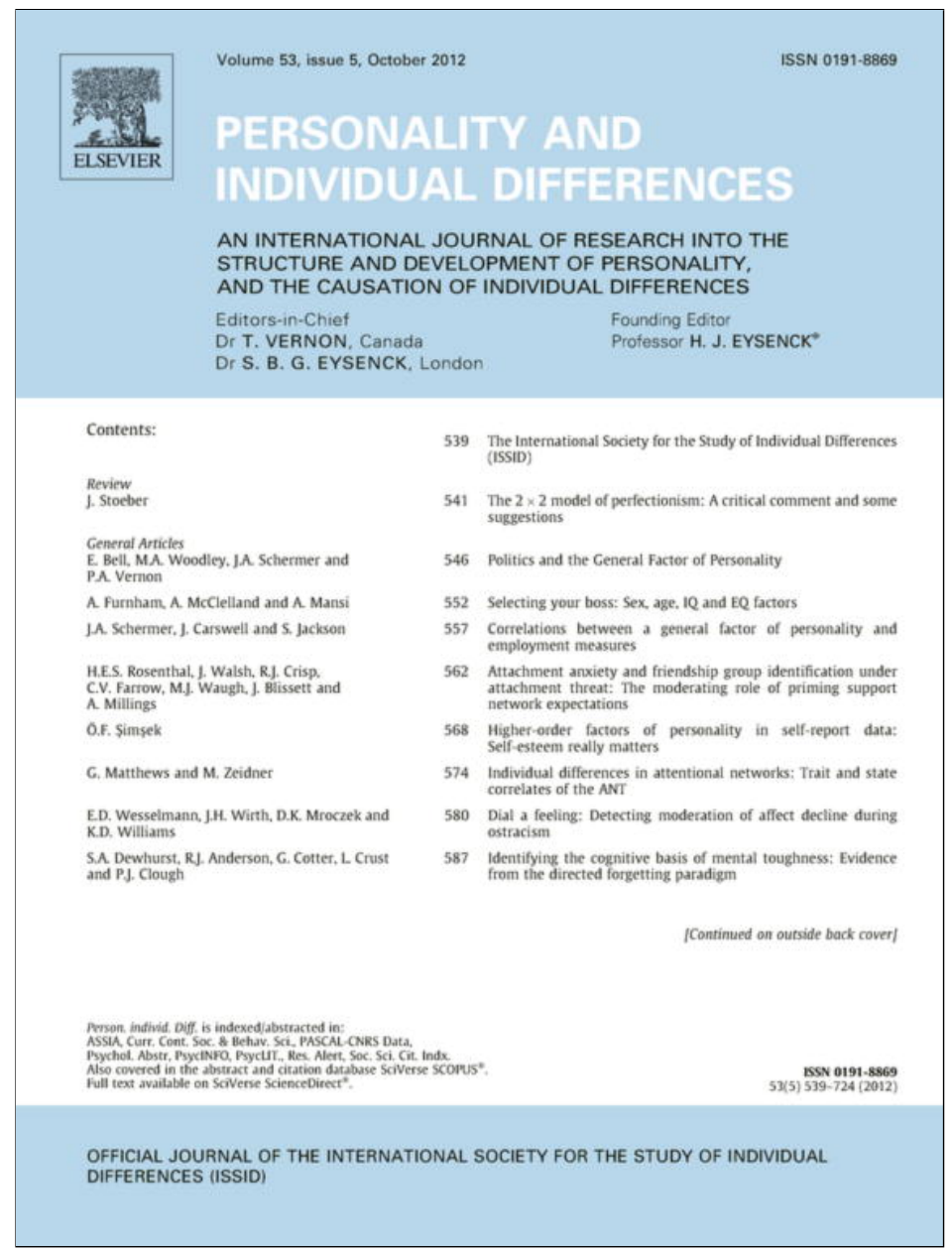

This article appeared in a journal published by Elsevier. The attached copy is furnished to the author for internal non-commercial research and education use, including for instruction at the authors institution and sharing with colleagues.

Other uses, including reproduction and distribution, or selling or licensing copies, or posting to personal, institutional or third party websites are prohibited.

In most cases authors are permitted to post their version of the article (e.g. in Word or Tex form) to their personal website or institutional repository. Authors requiring further information regarding Elsevier's archiving and manuscript policies are encouraged to visit:

http://www.elsevier.com/copyright 


\title{
Exploring the relationship between workaholism and workplace aggressive behaviour: The role of job-related emotion
}

\author{
Cristian Balducci ${ }^{\mathrm{a}, *}$, Monica Cecchin ${ }^{\mathrm{b}, 1}$, Franco Fraccaroli ${ }^{\mathrm{c}, 2}$, Wilmar B. Schaufeli ${ }^{\mathrm{d}, 3}$ \\ ${ }^{a}$ University of Bologna, Via dei Bersaglieri, 6/C - 40125 Bologna (BO), Italy \\ ${ }^{\mathrm{b}}$ ULSS Asolo, Via Forestuzzo, 41 - 31011 Asolo (TV), Italy \\ ${ }^{\mathrm{C}}$ University of Trento, Palazzo Fedrigotti, Corso Bettini 31 - I-38068 Rovereto (TN), Italy \\ ${ }^{\mathrm{d}}$ Utrecht University, P.O. Box 80.140, 3508 TC Utrecht, The Netherlands
}

\section{A R T I C L E I N F O}

\section{Article history:}

Received 28 October 2011

Received in revised form 19 April 2012

Accepted 7 May 2012

Available online 4 June 2012

\section{Keywords:}

Workplace aggression

Bullying

Abusive behaviour

Workaholism

Role stressors

\begin{abstract}
A B S T R A C T
Most research on workaholism has been devoted to the refinement of the construct and to the study of its psychological health correlates. In the present study, we contribute to a better understanding of the interpersonal and organizational consequences of workaholism by investigating its relationship with workplace aggressive behaviour. Drawing on well-established models of workplace aggression, we hypothesised that workaholism would be related to aggressive behaviour over and above working conditions (e.g. interpersonal conflict), which are widely known for their potential to trigger aggressive behaviour. Furthermore, we also hypothesised that job-related affective states (specifically high-arousal negative affective states) would mediate the workaholism-aggressive behaviour relationship. We tested the hypotheses in two different samples of employees $(N=574$, and $N=282)$ by using hierarchical regression and bootstrap multiple mediation analyses. Results were in line with predictions in both samples, suggesting that workaholism is an important factor as far as workplace aggression is concerned.
\end{abstract}

๑) 2012 Elsevier Ltd. All rights reserved.

\section{Introduction}

The world of work has changed profoundly in recent years (Näswall, Hellgren, \& Sverke, 2008). For example, there has been a progressive blurring of the boundaries between work and other life spheres, and clear role definition at work has become the exception rather than the norm. In this context, some authors (Cunningham, De La Rosa, \& Jex, 2008) have argued that personal characteristics will prove to be more significant than working conditions in explaining individual reactions to work. One such personal characteristic that has received increasing attention in the last decade or so is workaholism, which was initially defined as a compulsion or uncontrollable need to work incessantly (Oates, 1968).

Most research on workaholism to date has been devoted to refinement of the construct and to the study of its health effects. Although different conceptualizations of the phenomenon exist (see McMillan \& O'Driscoll, 2006), a definition that is gaining consensus emphasises two core components of workaholism: working excessively hard, and the existence of a strong and irresistible inner

\footnotetext{
* Corresponding author. Tel.: +39 051 2092722; fax: +39 051234036.

E-mail addresses: cristian.balducci3@unibo.it (C. Balducci), monica.cecchin@ ulssasolo.ven.it (M. Cecchin), franco.fraccaroli@unitn.it (F. Fraccaroli),w.schaufeli@ uu.nl (W.B. Schaufeli).

1 Tel.: +390423 5261 .

2 Tel.: +39 0464 808609; fax: +390464808411.

3 Tel.: +31 30 2539093; fax: +31302537482.
}

drive to work (Schaufeli, Taris, \& Bakker, 2008; see also McMillan, O'Driscoll, \& Burke, 2003). The former refers to the behavioural and observable component of workaholism, and points to the exceptional amount of time that workaholics tend to allocate to work. The latter refers to the cognitive component of workaholism, and underlines the existence of an obsession for work - i.e. the persistent focus on work-related matters, even when the individual is not working. Furthermore, evidence is emerging that workaholism is a relatively stable individual characteristic (e.g. Burke, Matthiesen, \& Pallesen, 2006).

As far as the health consequences of workaholism are concerned, research has shown that workaholism is negatively related to job satisfaction (e.g. Aziz \& Zickar, 2006) and a number of health outcomes such as burnout and psychosomatic complaints (e.g. Kubota et al., 2010; Schaufeli, Bakker, Van der Heijden, \& Prins, 2009).

In the present study we explore a potential correlate of workaholism that has not received attention to date, namely workplace aggression, which may be defined as physically or psychologically harmful behaviour directed toward co-workers or others in a work-related context (Schat \& Kelloway, 2005). Workplace aggression, in its different conceptualizations (interpersonal deviance, counterproductive work behaviour, workplace harassment, etc.), has received increasing attention in the last decade or so (see Hershcovis et al., 2007) and there is now convincing evidence that it is a phenomenon widespread in modern work organizations 
(Barling, Dupré, \& Kelloway, 2009; European Foundation for the Improvement of Living \& Working Conditions, 2006).

We argue that there are strong theoretical reasons as well as some indirect empirical evidence, for a relationship between workaholism and workplace aggression. First of all, common definitions of workaholism fit well with what has been called the 'hot temperament' (Anderson \& Pearson, 1999), defined as being high in emotional reactivity and low in self-regulative capacity, which is a risk factor for engaging in aggressive behaviour at work (e.g. Barling et al., 2009). Furthermore, models of aggressive behaviour (Neuman \& Baron, 2005; Spector \& Fox, 2005) emphasize the role of critical internal states, particularly high arousal negative emotions (i.e. anger and anxiety), as the immediate antecedents of aggression. These critical internal states are fuelled in part by contextual factors, among which interpersonal conflict and role stressors seem to play a prominent role (Balducci, Schaufeli, \& Fraccaroli, 2011; Hershcovis et al., 2007; Spector \& Fox, 2005). However, personal characteristics are also of importance (Barling et al., 2009; Hershcovis et al., 2007; Spector, 2011). Since workaholics report low subjective well-being (e.g. Schaufeli et al., 2009) it is highly likely that they will tend to experience those critical internal states which trigger aggressive behaviour more frequently (see also Clark, Lelchook, \& Taylor, 2010). Finally, a recent study (Shimazu, Schaufeli, \& Taris, 2010) found that workaholism was positively related to emotional discharge as a coping strategy; i.e. openly venting one's negative emotions to others. It is possible, and indeed likely, that this discharge takes the form of aggressive behaviour.

These considerations led us to formulate and test the following hypotheses:

(1) Workaholism would be positively related to aggressive behaviour, even after controlling for powerful contextual predictors of aggression (i.e. role conflict, role ambiguity, and interpersonal conflict - see Spector \& Fox, 2005).

(2) The experience of job-related negative emotion, particularly high arousal negative emotion (Neuman \& Baron, 2005), would mediate the workaholism-aggressive behaviour relationship.

\section{Materials and methods}

\subsection{Participants}

Two different samples of participants were available for the analyses. In both cases data are based on self-report anonymous questionnaires administered during working hours. Sample 1 data were collected in a national healthcare agency in Northern Italy. A total of 574 employees participated ( $76.9 \%$ females). The response rate varied from $48.2 \%$ to $93.3 \%$ in the various departments. The age classes most represented were $30-39$ years (37.5\%) and 40-49 years (34.1\%). Participants were medical doctors (6.5\%), nurses (67.4\%), administrative staff (24.1\%), and others (e.g. personnel responsible for cleaning rooms) (2.0\%). Most of the participants (94.9\%) had a permanent job contract. Sample 2 data were collected in a public environmental protection agency in Central Italy. A total of 282 employees in non-managerial positions participated (response rate: $54.2 \%$ ), $44.7 \%$ of whom were females. The most represented age classes were $30-39$ years (34.8\%) and $50-59$ years (31.2\%). Participants had an administrative role in $38.2 \%$ of the cases and a technical role in the remaining cases (61.8\%). The job contract was of a permanent type in $78.1 \%$ of the cases.

\subsection{Instruments}

Workaholism was measured by using the Dutch Workaholism Scale (DUWAS; Schaufeli et al., 2008). This tool investigates the two components of workaholism (i.e. working compulsively and working excessively) by means of ten items, examples of which are the following: "I feel that there's something inside me that drives me to work hard" (working compulsively) and "I stay busy and keep many irons in the fire" (working excessively). Responses could range from 1 ("Never or almost never") to 4 ("Almost always or always"). Since both components contribute to the workaholic syndrome (Schaufeli et al., 2009), an overall workaholism score was obtained. Cronbach's alpha was adequate in both samples $(.81 / .82)$. For this and the other measures described below, the score used for the analyses was derived by computing the total scale score for each participant and then dividing the result by the number of scale items.

Role stressors were operationalized in terms of role conflict and role ambiguity. Role conflict was measured by using five items (e.g. "I receive incompatible requests from two or more people") from the role conflict scale developed by Rizzo, House, and Lirtzman (1970). Responses ranged from 1 ("Entirely true") to 5 ("Entirely false"), with items being reverse coded before the scale total was computed. Alpha was .70 in Sample 1 and .75 in Sample 2. Role ambiguity was measured by using five items from a scale developed by the same authors (Rizzo et al., 1970), with an example item being: "I know what my responsibilities are". The response format was the same as for the role conflict scale. Cronbach's alpha was $.73 / .76$ for this scale.

Interpersonal conflict was assessed by using a 9-item version (Notelaers \& Einarsen, 2008) of the Negative Acts QuestionnaireRevised (NAQ-R; Einarsen, Hoel, \& Notelaers, 2009), which explores targets' experiences of bullying behaviour - an extreme form of interpersonal conflict (Einarsen, Hoel, Zapf, \& Cooper, 2011). The NAQ-R investigates how often the respondent has been subjected to a number of negative behaviours at work in the last six months, such as "You have been constantly criticized for your work and effort". Responses varied from 1 ("Never") to 5 ("Daily"). We obtained a Cronbach's alpha of $.82 / .88$ for the adopted version of the scale.

Work-related emotion was assessed by using a shortened 8-item version of the Job-related Affective Well-being Scale (JAWS; Van Katwyk, Fox, Spector, \& Kelloway, 2000). The JAWS investigates the frequency of experience of positive and negative affective states associated with an individual's work across the previous 30 days, with responses given on a 5-point scale ranging from 1 ("Never") to 5 ("Very often"). Based on a two-dimensional model of work-related affect which builds upon the work of Russell (1980), specific subscales may be derived from the JAWS. We derived the following four 2-item subscales: high-arousal negative affect (e.g. "Anger"; $r$ : .49/.67); low-arousal negative affect (e.g. "Pessimism"; $r$ : .67/.75); high-arousal positive affect (e.g. "Enthusiasm"; $r$ : .75/.75), and low-arousal positive affect (e.g. "Satisfaction"; $r$ : .48/.47).

Aggressive behaviour was investigated by the nine items comprising the workplace bullying measure (see above), which were rewritten in terms of the actor's perspective of aggression (e.g. "You have constantly criticized someone for his/her work and effort"). Responses varied from 1 ("Never") to 5 ("Daily"). Cronbach's alpha was .76/.67 for the scale. The emerged value of alpha in Sample 2 was slightly below the commonly-accepted threshold of .70; however, for less clearly delimited psychological phenomena (of which aggressive behaviour can be considered an example, see Spector et al., 2006), measurement scales which attain an alpha of .60 to .70 can be regarded as acceptable (Kline, 1999).

\subsection{Analytical strategy}

In order to test for the relationship between workaholism and workplace aggression (Hypothesis 1), we conducted hierarchical 
regression analysis. Workaholism was included in the last (i.e. third) step of the regression; sociodemographic variables were included in step 1, by way of control variables, while in step 2 role conflict, role ambiguity and interpersonal conflict were included. To explore the mediating effect of job-related emotion - particularly high-arousal negative emotion - on the workaholism-aggressive behaviour relationship, we conducted bootstrapping analysis by using the method described by Preacher and Hayes (2008) for estimating direct and indirect effects with multiple mediators. Since we had two samples available for the analyses, we adopted a cross-validation approach whereby both hypotheses were tested in Sample 1 first, and then the results were cross-validated in Sample 2.

\section{Results}

Descriptive statistics of the study variables and their intercorrelations (Pearson's $r$ ) are presented in Table 1 . To note is that, in both samples, workaholism was positively and significantly related to aggressive behaviour ( $r=.25$ in Sample 1 and $r=.18$ in Sample 2).

Table 2 and Table 3 report the results of hierarchical regression analysis by which we tested Hypothesis 1, that assumes that workaholism would be a significant correlate of aggressive behaviour.

In both samples, job stressors (i.e. role conflict, role ambiguity and interpersonal conflict) explained more than $20 \%$ of variance in aggressive behaviour; however, in both cases it was only interpersonal conflict that contributed significantly $(\beta=.410, p<.001$ in Sample 1; $\beta=.363, p<.001$ in Sample 2). Even after controlling for sociodemographic variables and job stressors, workaholism explained a significant amount of variance in aggressive behaviour: that is, $1 \%$ in Sample 1 and $1.5 \%$ in Sample 2. Parameter estimates $(\beta=.111, p<.05$ in Sample $1 ; \beta=.128, p<.05$ in Sample 2$)$ confirmed the results of the preliminary correlational analysis: increasing levels of workaholism were related with a higher frequency of aggressive behaviour. Hence, Hypothesis 1 was supported.

Fig. 1 and Fig. 2 report some of the results regarding Hypothesis 2 , that job-related negative emotion, particularly high-arousal negative emotion, would mediate the workaholism-aggressive behaviour relationship. Results of the analysis of Sample 1 (reported as unstandardized coefficients) indicated that the total effect of workaholism on aggressive behaviour (total effect $=.114$, $t=2.988 ; p<.01$ ) became non-significant when job-related negative emotion was included in the model (direct effect of workaholism $=.048, t=1.402$; n.s.). Furthermore, the analysis revealed that the total indirect effect of job-related negative emotion on aggressive behaviour (i.e. the difference between the total and direct effects) was significant, with a point estimate of .065 and a 95\% BCa (bias-corrected and accelerated) bootstrap confidence interval of .019 to .125 . Thus, job-related emotion fully mediated the association between workaholism and aggressive behaviour. However, the specific indirect effects of each tested mediator showed that only high-arousal negative emotion was a significant mediator, with a point estimate of .058 and $95 \% \mathrm{BCa} C \mathrm{Cl}$ of .020 to .108 . These results were replicated in Sample 2; here, the total effect of workaholism on aggressive behaviour (total effect $=.168, t=5.656$; $p<.001$ ) became smaller when job-related negative emotion was included in the model (direct effect of workaholism $=.112$, $t=3.515 ; p<.001$ ). The analysis revealed that the total indirect effect of job-related negative emotion on aggressive behaviour was significant, with a point estimate of .056 and a $95 \%$ BCa bootstrap

Table 1

Properties and Pearson's product moment correlations of main study variables.

\begin{tabular}{|c|c|c|c|c|c|c|c|c|c|c|c|c|c|c|}
\hline & \multicolumn{2}{|c|}{$\begin{array}{l}\text { Sample } 1 \\
(N=574)\end{array}$} & \multicolumn{2}{|c|}{$\begin{array}{l}\text { Sample } 2 \\
(N=282)\end{array}$} & \multirow[t]{2}{*}{1} & \multirow[t]{2}{*}{2} & \multirow[t]{2}{*}{3} & \multirow[t]{2}{*}{4} & \multirow[t]{2}{*}{5} & \multirow[t]{2}{*}{6} & \multirow[t]{2}{*}{7} & \multirow[t]{2}{*}{8} & \multirow[t]{2}{*}{9} & \multirow[t]{2}{*}{10} \\
\hline & $M$ & $S D$ & $M$ & $S D$ & & & & & & & & & & \\
\hline 1- Aggressive behaviour & 1.32 & 0.36 & 1.31 & 0.34 & - & $.18^{* * *}$ & $.31^{* * *}$ & $.33^{* *}$ & $.52^{* *}$ & $.51^{* *}$ & $.36^{* *}$ & -.02 & $-.13^{*}$ & -.05 \\
\hline 2- Workaholism & 2.15 & 0.54 & 1.99 & 0.56 & $.25^{* *}$ & - & $.20^{* *}$ & $.20^{* *}$ & $.21^{* *}$ & $.20^{* *}$ & $.24^{* *}$ & .12 & -.02 & .05 \\
\hline 3- Role conflict & 2.84 & 0.90 & 2.35 & 0.90 & $.25^{* *}$ & $.23^{* *}$ & - & $.44^{* *}$ & $.42^{* *}$ & $.39^{* *}$ & $.38^{* *}$ & -.08 & $-.20^{* *}$ & -.04 \\
\hline 4- Role ambiguity & 2.08 & 0.60 & 2.30 & 0.75 & $.16^{* *}$ & $.18^{* *}$ & $.44^{* *}$ & - & $.45^{* *}$ & $.41^{* *}$ & $.43^{* *}$ & $-.16^{*}$ & $-.29^{* *}$ & .02 \\
\hline 5- Interpersonal conflict & 1.51 & 0.59 & 1.50 & 0.64 & $.45^{* *}$ & $.34^{* *}$ & $.36^{* *}$ & $.30^{* *}$ & - & $.59^{* *}$ & $.44^{* *}$ & .01 & $-.24^{* *}$ & .08 \\
\hline 6- High-arousal negative affect & 2.18 & 0.94 & 2.33 & 1.18 & $.28^{* *}$ & $.34^{* *}$ & $.39^{* *}$ & $.35^{* *}$ & $.35^{* *}$ & - & $.65^{* *}$ & -.05 & $-.28^{* *}$ & $.14^{*}$ \\
\hline 7- Low-arousal negative affect & 2.36 & 1.00 & 2.46 & 1.17 & $.19^{* *}$ & $.29^{* *}$ & $.35^{* *}$ & $.32^{* *}$ & $.29^{* *}$ & $.58^{* *}$ & - & $-.13^{*}$ & $-.30^{* *}$ & $.17^{* *}$ \\
\hline 8- High-arousal positive affect & 3.23 & 0.99 & 2.60 & 1.08 & .01 & .06 & $-.24^{* *}$ & $-.16^{* *}$ & -.04 & $-.14^{* *}$ & $-.13^{* *}$ & - & $.64^{* *}$ & .06 \\
\hline 9- Low arousal positive affect & 3.16 & 0.95 & 2.88 & 1.02 & $-.09^{*}$ & $-.18^{* *}$ & $-.29^{* *}$ & $-.27^{* *}$ & $-.17^{* *}$ & $-.27^{* *}$ & $-.32^{* *}$ & .60 & - & -.05 \\
\hline $10-$ Gender $(0=$ male; $1=$ female $)$ & 0.77 & 0.42 & 0.45 & 0.50 & $-.13^{* *}$ & .04 & -.09 & -.05 & -.05 & -.05 & .01 & $.11^{* *}$ & .04 & - \\
\hline
\end{tabular}

${ }_{* *}^{*} p<.05$.

** $p<.01$.

Table 2

Hierarchical regression analysis (Sample 1 data; $N=574$ ) predicting aggressive behaviour from sociodemographics, role stressors, interpersonal conflict and workaholism.

\begin{tabular}{|c|c|c|c|}
\hline Predictors & Step $1 \beta$ & Step $2 \beta$ & Step $3 \beta$ \\
\hline Gender $(0=$ Male, $1=$ Female $)$ & $-.118^{*}$ & -.074 & $-.087^{p=.067}$ \\
\hline Age & -.030 & .022 & .034 \\
\hline Organizational role 1 ( $0=$ All others, $1=$ Administrative $)$ & .049 & .052 & .081 \\
\hline Organizational role $2(0=$ All others, $1=$ Nurses $)$ & .068 & .122 & .151 \\
\hline Organizational role $3(0=$ All others, $1=$ Other workers (e.g. cleaning staff $))$ & .119 & $.136^{*}$ & $.146^{*}$ \\
\hline Tenure $(0=5$ years or less, $1=$ more than 5 years $)$ & -.006 & -.066 & -.075 \\
\hline Role conflict & & .074 & .055 \\
\hline Role ambiguity & & -.021 & -.019 \\
\hline Interpersonal conflict & & $.445^{* * *}$ & $.410^{* * *}$ \\
\hline Workaholism & & & $.111^{*}$ \\
\hline$\Delta R^{2}$ & .020 & $.214^{* * *}$ & $.010^{*}$ \\
\hline
\end{tabular}

* $p<.05$.

** $p<.01$.

*** $p<.001$. 
Table 3

Hierarchical regression analysis (Sample 2 data; $N=282$ ) predicting aggressive behaviour from sociodemographics, role stressors, interpersonal conflict and workaholism.

\begin{tabular}{|c|c|c|c|}
\hline Predictors & Step $1 \beta$ & Step $2 \beta$ & Step $3 \beta$ \\
\hline Gender $(0=$ Male, $1=$ Female $)$ & .026 & -.017 & -.016 \\
\hline Age & -.012 & .000 & .007 \\
\hline Organizational role $(0=$ Technician, $1=$ Administrative $)$ & -.069 & -.011 & .002 \\
\hline Tenure $(0=5$ years or less, $1=$ more than 5 years $)$ & .123 & .109 & .129 \\
\hline Role conflict & & .047 & .028 \\
\hline Role ambiguity & & $.141^{*}$ & $.140^{*}$ \\
\hline Interpersonal conflict & & $.382^{* * *}$ & $.363^{* * *}$ \\
\hline Workaholism & & & $.128^{*}$ \\
\hline$\Delta R^{2}$ & .021 & $.238^{* * *}$ & $.015^{*}$ \\
\hline
\end{tabular}

${ }^{*} p<.05$.

** $p<.01$

$p<.001$.

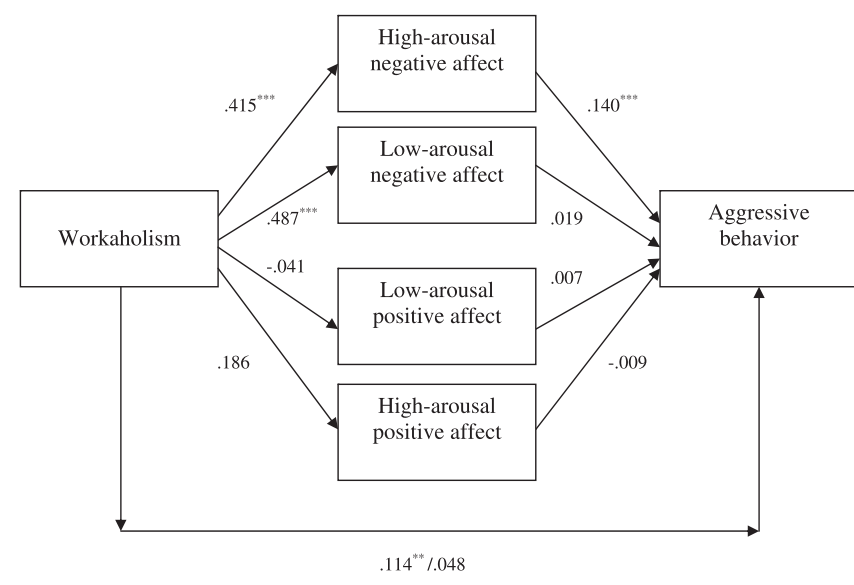

Fig. 1. Multiple mediation analysis with job-related negative affect mediating the workaholism-aggressive behaviour relationship (Sample 1 data; $N=574$ ). Note. Unstandardized regression coefficients are reported in paths. ${ }^{*} p<.05$. ${ }^{* *} p<.01$. ${ }^{* * *} p<.001$

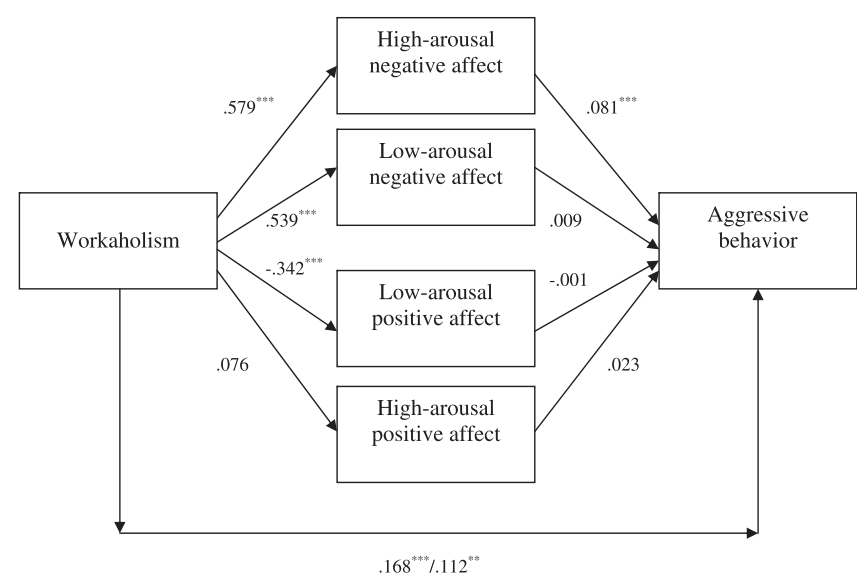

Fig. 2. Multiple mediation analysis with job-related negative affect mediating the workaholism-aggressive behaviour relationship (Sample 2 data; $N=282$ ). Note Unstandardized regression coefficients are reported in paths. ${ }^{*} p<.05$. ${ }^{* *} p<.01$. ${ }^{* * *} p<.001$.

CI of .026 to .103 . Thus, job-related emotion partially mediated the workaholism-aggressive behaviour relationship. However, it was again only high-arousal negative emotion that was a significant mediator, with a point estimate of .047 and $95 \% \mathrm{BCa} C \mathrm{Cl}$ of .018 to .081. These results provided substantial support to Hypothesis 2 .

\section{Discussion}

In line with our first hypothesis, we found that workaholism explained unique variance in aggressive behaviour at work, even after role stressors and interpersonal conflict, which are among the most powerful contextual triggers of workplace aggressive behaviour (e.g. Spector \& Fox, 2005), had been controlled for. Although the percentage of unique variance in workplace aggressive behaviour explained by workaholism was not high ( $1 \%$ and $1.5 \%$ in the two samples), it is to be noted that such a percentage of variance may still represent a material effect (Cohen, Cohen, West, \& Aiken, 2003, p. 151). The obtained results constitute an original finding, since previous research has focused mostly on the health consequences of workaholism, while less attention has been paid to an examination of the social-organizational consequences of the phenomenon. From the perspective of workplace aggression research, scholars have traditionally focused on personality characteristics such as trait anger and negative affectivity as antecedents of workplace aggression (Hershcovis et al., 2007). More recently, Spector (2011) has suggested additional personal dispositions which may also be involved in aggressive behaviour: narcissism, effortful control, hostile attribution bias, and external locus of control. However, the potential effect of workaholism on workplace aggression has not been considered thus far.

It is also quite possible that workaholism, besides acting as an antecedent of workplace aggression, also acts as a moderator of contextual conditions such as interpersonal conflict and role stressors. Previous research has not provided strong evidence for the moderating role of personality factors on workplace aggression (Hershcovis et al., 2007). However, this is an area that warrants further attention in future research.

In line with our second hypothesis, we found that job-related emotion was a critical mediator in the workaholism-aggression relationship. Theoretical models of workplace aggression (e.g. Spector \& Fox, 2005) postulate that emotion - which is considered to be a functional mechanism which signals to the individual the need to act on the environment - is a crucial mediator in the relationship between work environment and personality factors, on the one hand, and aggressive behaviour on the other. However, it is high-arousal negative emotion (e.g. anxiety) that is particularly related to aggressive behaviour, and this serves, perhaps, as a means of discharging the negative affective state and protecting one's health from its long-term effects (Krischer, Penney, \& Hunter, 2010). Since workaholism is by definition characterized by obsession and compulsiveness, thus falling within the area of anxiety-related dysfunctions, it fuels high-arousal negative internal states (e.g. anxiety). Furthermore, workaholism may also lead to such high arousal negative states indirectly, for example through the 
reactions of co-workers, with whom workaholics have difficulty in cooperating productively. In either case, the crucial point is that workaholics tend to commonly experience the emotional antecedents of aggressive behaviour.

Overall, the results of this study further contribute to gainsaying the widespread belief (see Porter, 1996) that workaholism may be functional from an organizational perspective. Previous research has already revealed that workaholics are not always the most productive workers, and that they tend to create difficulties for their co-workers because of their inflexibility and perfectionism (Killinger, 2006; Schaufeli et al., 2008; Shimazu et al., 2010). In this study, we have identified a further problem which may be associated with workaholism, which suggests that workaholism may be a more serious problem for organizations than previously thought.

A limitation of the present study is that it has focused on employees of public sector organizations. Hence we do not know whether its findings can be generalized. However, previous research has already supported the link between workaholism and work-related negative emotions such as anxiety in different kinds of organizations and jobs (e.g. Shimazu et al., 2010) and, similarly, work-related negative emotions have been linked with aggressive behaviour in different organizational contexts (Fox, Spector, \& Miles, 2001). Thus we have some confidence that the results of our study may be replicated by future research.

Another limitation of this study is that it has been cross-sectional in nature, meaning that causal interpretations are precluded. However, to strengthen our results, we adopted a cross-validation approach by using two independent samples obtained from different organizations. We also tested hypotheses derived from robust theories of human aggression and work-related stress (Neuman \& Baron, 2005; Spector \& Fox, 2005), and from evidence based on longitudinal data collected in laboratory, as well as in organizational, settings (e.g. Ilies, Johnson, Judge, \& Keeney, 2011; Kivisto, Moore, Elkins, \& Rhatigan, 2009). We thus believe that our findings could be replicated also longitudinally.

A third limitation of the study is that all the data are self-reported, which may inflate the correlations between variables due to common method variance generated by sources such as social desirability (Spector, 2006). However, it is also true that the effect of common method variance should be evaluated case by case. For example, if social desirability affects the constructs of interest in different directions, it is possible that their relationships are being underestimated rather than overestimated (Chan, 2009). In this study, while social desirability could have caused underreporting of aggressive behaviour, this should be less the case for reports of workaholism, aspects of which (e.g. continuing to work after colleagues have called it quits for the day) may also be considered to be socially desirable.

As far as the implications of the present study are concerned, our results suggest that prevention of workplace aggression should also consider workaholism. Schaufeli et al. (2009) have suggested that workaholic behaviour may be limited by training supervisors to pay attention to the work habits of their subordinates, and to encourage them to maintain a balanced life. This should defuse the path to aggressive behaviour initiated by workaholism. Other preventive interventions have also been proposed (Van Wijhe, Peeters, \& Schaufeli, 2010); however, to our knowledge there is no evidence for their effectiveness. Schaufeli et al. (2009) also suggest that workaholics could be referred to an occupational physician for personal counselling. Of course, this entails workaholics must be understood as individuals with psychological and behavioural problems, which is not always the case. This means that at present there is a need to disseminate adequate knowledge on the potential costs of workaholism.

\section{References}

Anderson, L. M., \& Pearson, C. M. (1999). Tit for tat? The spiraling effect of incivility in the workplace. Academy of Management Review, 24(3), 452-471.

Aziz, S., \& Zickar, M. J. (2006). A cluster analysis investigation of workaholism as a syndrome. Journal of Occupational Health Psychology, 11, 52-62.

Balducci, C., Schaufeli, W. B., \& Fraccaroli, F. (2011). The Job Demands-Resources model and counterproductive work behaviour: The role of job-related affect. European Journal of Work and Organizational Psychology, 20(4), 467-496.

Barling, J., Dupré, K. E., \& Kelloway, E. K. (2009). Predicting workplace aggression and violence. Annual Review of Psychology, 60, 671-692.

Burke, R. J., Matthiesen, S. B., \& Pallesen, S. (2006). Personality correlates of workaholism. Personality and Individual Differences, 40, 1223-1233.

Chan, D. (2009). So why ask me? Are self-report data really that bad? In C. E. Lance \& R. J. Vandenberg (Eds.), Statistical and methodological myths and urban legends (pp. 309-336). New York: Routledge.

Clark, M. A., Lelchook, A. M., \& Taylor, M. L. (2010). Beyond the Big Five: How narcissism, perfectionism, and dispositional affect relate to workaholism. Personality and Individual differences, 48, 786-891.

Cohen, J., Cohen, P., West, S. G., \& Aiken, L. S. (2003). Applied multiple regression/ correlation analysis for the behavioral sciences. Mahwah, NJ: Lawrence Erlbaum Associates.

Cunningham, C. J. L., De La Rosa, G. M., \& Jex, S. M. (2008). The dynamic influence of individual characteristics on employee well-being: A review of the theory, research, and future directions. In K. Näswall, J. Hellgren, \& M. Sverke (Eds.), The individual in the changing working life (pp. 258-283). New York: Cambridge University Press.

Einarsen, S., Hoel, H., \& Notelaers, G. (2009). Measuring exposure to bullying and harassment at work: Validity, factor structure and psychometric properties of the Negative Acts Questionnaire-Revised. Work \&' Stress, 23(1), 24-44.

Einarsen, S., Hoel, H., Zapf, D., \& Cooper, C. L. (2011). The concept of bullying and harassment at work: The European tradition. In S. Einarsen, H. Hoel, D. Zapf, \& C. L. Cooper (Eds.), Bullying and harassment in the workplace. Developments in theory, research, and practice (pp. 3-39). Boca Raton, FL: CRC Press.

European Foundation for the Improvement of Living and Working Conditions (2006). Fourth European working conditions survey. Luxembourg: Office for Official Publications of the European Communities.

Fox, S., Spector, P. E., \& Miles, D. (2001). Counterproductive work behaviour (CWB) in response to job stressors and organizational justice: Some mediator and moderator tests for autonomy and emotions. Journal of Vocational Behaviour, 59, 291-309.

Hershcovis, M. S., Turner, N., Barling, J., Arnold, K. A., Dupré, K. E., \& Inness, M. (2007). Predicting workplace aggression: A meta-analysis. Journal of Applied Psychology, 92(1), 228-238.

Ilies, R., Johnson, M. D., Judge, T. A., \& Keeney, J. (2011). A within-individual study of interpersonal conflict as a work stressor: Dispositional and situational moderators. Journal of Organizational Behaviour, 32(1), 44-64.

Killinger, B. (2006). The workaholic breakdown syndrome. In R. J. Burke (Ed.), Research companion to working time and work addiction (pp. 61-88). Northampton, MA: Edward Elgar.

Kivisto, A. J., Moore, T. M., Elkins, S. R., \& Rhatigan, D. L. (2009). The effects of PTSD symptomatology on laboratory based aggression. Journal of Traumatic Stress, $22(4), 344-347$

Kline, P. (1999). The handbook of psychological testing (2nd ed.). London: Routledge.

Krischer, M. M., Penney, L. M., \& Hunter, E. M. (2010). Can counterproductive work behaviours be productive? CWB as emotion-focused coping. Journal of Occupational Health Psychology, 15(2), 154-166.

Kubota, K., Shimazu, A., Kawakami, N., Takahashi, M., Nakata, A., \& Schaufeli, W. B. (2010). Association between workaholism and sleep problems among hospital nurses. Industrial Health, 48, 864-871.

McMillan, L. H. W., \& O'Driscoll, M. P. (2006). Exploring new frontiers to generate an integrated definition of workaholism. In R. Burke (Ed.), Research companion to working time and work addiction (pp. 89-107). Cheltenham, UK: Edward Elgar.

McMillan, L. H. W., O'Driscoll, M. P., \& Burke, R. J. (2003). Workaholism: A review of theory, research, and future directions. International Review of Industrial and Organizational Psychology, 18, 167-189.

Näswall, K., Hellgren, J., \& Sverke, M. (2008). The individual in the changing working life. New York: Cambridge University Press.

Neuman, J. H., \& Baron, R. A. (2005). Aggression in the workplace: A social psychological perspective. In S. Fox \& P. E. Spector (Eds.), Counterproductive work behaviour (pp. 13-40). Washington, DC: American Psychological Association.

Notelaers, G., \& Einarsen, S. (2008). The construction and validity of the Short Negative Acts Questionnaire. In Paper presented at the 6th international conference on bullying and harassment in the workplace. Montreal (Canada).

Oates, W. (1968). On being a workaholic (a serious jest). Pastoral Psychology, 19, $16-20$.

Porter, G. (1996). Organizational impact of workaholism: Suggestions for researching the negative outcomes of excessive work. Journal of Occupational Health Psychology, 1(1), 70-84.

Preacher, K. J., \& Hayes, A. F. (2008). Asymptotic and resampling strategies for assessing and comparing indirect effects in multiple mediator models. Behaviour Research Methods, 40(3), 879-891.

Rizzo, J. R., House, R. J., \& Lirtzman, S. I. (1970). Role conflict and ambiguity in complex organizations. Administrative Science Quarterly, 15(2), 150-163. 
Russell, J. A. (1980). A circumplex model of affect. Journal of Personality and Social Psychology, 39(6), 1161-1178.

Schat, A. C. H., \& Kelloway, E. K. (2005). Workplace violence. In J. Barling, E. K. Kelloway, \& M. Frone (Eds.), Handbook of work stress (pp. 189-218). Thousand Oaks, CA: Sage.

Schaufeli, W. B., Bakker, A. B., Van der Heijden, F. M. M. A., \& Prins, J. T. (2009) Workaholism, burnout and well-being among junior doctors: The mediating role of role conflict. Work \& Stress, 23, 155-172.

Schaufeli, W. B., Taris, T. W., \& Bakker, A. B. (2008). It takes two to tango. Workaholism is working excessively and working compulsively. In R. J. Burke \& C. L. Cooper (Eds.), The long work hours culture. Causes, consequences and choices (pp. 203-226). Bingley, UK: Emerald.

Shimazu, A., Schaufeli, W. B., \& Taris, T. W. (2010). How does workaholism affect worker health and performance? The mediating role of coping. International Journal of Behavioural Medicine, 17, 154-160.

Spector, P. E. (2006). Method variance in organizational research. Truth or urban legend? Organizational Research Methods, 9(2), 221-232.
Spector, P. E. (2011). The relationship of personality to counterproductive work behaviour (CWB): An integration of perspectives. Human Resource Management Review, 21, 342-352.

Spector, P. E., \& Fox, S. (2005). The stressor-emotion model of counterproductive work behaviour. In S. Fox \& P. E. Spector (Eds.), Counterproductive work behaviour (pp. 151-174). Washington, DC: American Psychological Association.

Spector, P. E., Fox, S., Penney, L. M., Bruursema, K., Goh, A., \& Kessler, S. (2006). The dimensionality of counterproductivity: Are all counterproductive behaviors created equal? Journal of Vocational Behaviour, 68, 446-460.

Van Katwyk, P. T., Fox, S., Spector, P. E., \& Kelloway, E. K. (2000). Using the Jobrelated Affective Well-being Scale (JAWS) to investigate affective responses to work stressors. Journal of Occupational Health Psychology, 5, 219-230.

Van Wijhe, C., Peeters, M. C. W., \& Schaufeli, W. B. (2010). Understanding and treating workaholism: Setting the stage for successful interventions. In R. J. Burke \& C. L. Cooper (Eds.), Risky business (pp. 107-134). Farnham, UK: Gower Publishing. 